\title{
Delayed Alarm
}

National Cancer Institute

\section{Source}

National Cancer Institute. Delayed Alarm. NCI Thesaurus. Code C63247.

A device alarm system operates with delay. 